\title{
Parasites, Politics and Public Science: The Promotion of Biological Control in Western Australia, 1900-1910
}

\section{EDWARD DEVESON*}

\begin{abstract}
Biological control of arthropods emerged as a scientific enterprise in the late nineteenth century and the orchard industry of California was an early centre of expertise. In 1900, as the Australian colonies prepared for Federation, each had a Government Entomologist attached to its agriculture department. The hiring of George Compere from California by the Western Australian Department of Agriculture began a controversial chapter in the early history of biological control that was linked to a late, local popularisation of acclimatisation. Compere became known as the 'travelling entomologist' and for a decade brought 'parasites' of pest insects from overseas and released them in Perth. His antagonistic disciplinary rhetoric and inflated claims for the 'parasite theory' created conflict with his counterparts in the eastern states. The resulting interstate entomological controversy was played out in the press, revealing the political use of science for institutional and even state identity. It is a story of transnational exchanges, chance discoveries and popular public science: popular because of the promise of a simple, natural solution to agricultural insect pests and because of the public nature of the disputes it generated between the experts. This microcosm contributes to the global historiography of acclimatisation, biological control,scientific exposition and the professionalisation of agricultural science.
\end{abstract}

KEYWORDS: biological control, entomology, George Compere, Walter Froggatt, Frederick Lowe, Alfred Koebele, Frazer Crawford, acclimatisation, settler agriculture

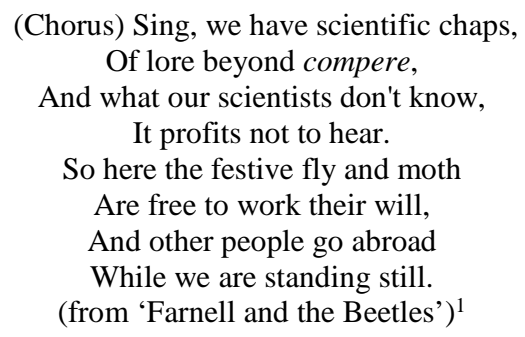

\author{
Behold! look! I'm Yankee Compere, \\ I track bugs to their distant lair, \\ And stuffs them in my hutch; \\ There's ne'er a soul knows what I do, \\ Blush! at Port Said, Whew! Timbuc \\ too...(Curtain.) \\ (from 'Bughunter Compere')2.
}

\section{Introduction}

The road that led to many ecological problems caused by invasive species was

littered with good intentions. Australians live with some glaring vertebrate examples:

the rabbit and fox introduced by acclimatisers; the cane toad introduced for

biological control; starlings and mynah birds released by both groups. There have 
also been great success stories, such as the biological control of prickly-pear cactuses by the Cactoblastis moth. Other than silkworms and honeybees, insects were not favoured by nineteenth century acclimatisation groups and no current insect pests are the inadvertent result of early biological control efforts. ${ }^{3}$

Many insect pests were accidentally introduced as a result of agricultural imports, however. Settler societies exchanged large quantities of domesticated plants and products and in doing so unwittingly shared insects from the new environments, as well as many from Europe. Concern over such unfortunate imports in the Australian colonies led to the first phytosanitary measures in the late nineteenth century. ${ }^{4}$ The early dominion government was not in a position to centralise entomological knowledge and only made import biosecurity uniform in 1908, with the Quarantine Act.

While the historiography of biological control of arthropods find its roots in eighteenth century natural history, it emerged as a successful scientific enterprise in the late nineteenth century, with the orchard industry of California an early centre of experimental exchanges. ${ }^{5}$ Born in Davenport Iowa, George Compere (1858-1928) came to California and worked in the booming Riverside orchard industry, becoming a manager in his twenties. ${ }^{6}$ He was one of the converts to the 'parasite theory' of biological control by natural enemies after seeing 'ladybirds make the woolly aphids curl up'. He gave up selling 'spraying dope', joined the Board of Horticulture as an inspector in 1891 and then as insect collector in $1899 .^{7}$ Biological control was taken up enthusiastically by entomologists worldwide and numerous trial introductions were made in the following decades under various degrees of scientific control. There was a variable rate of establishment of candidate species and subsequent 
calculations show a five to fifteen percent success rate in terms of control of target species throughout the twentieth century. ${ }^{8}$

The growth of biological control science in the early twentieth century was a response to 'alien incursions' of animals and plants that came with agricultural development. There was hardly any new crop that did not entrain 'mobile nature' in its wake, pests to halt its progress. ${ }^{9}$ Sometimes an emergent pest was 'native', more often it was 'foreign', but biogeographic origin, cultural or even racial nuances were irrelevant to its universal condemnation as unwanted. ${ }^{10}$ Nor did origin taint the positive image of any potential biocontrol saviour, unless time revealed it to be a destructor. This unpredictable lag in consequences was the principal reason for the development of stringent international codes applied to the import or release of exotic biological control agents. ${ }^{11}$

In contrast to the inadvertent arrival of many insect pests, the acclimatisation movement chose foreign plants and vertebrate animals for deliberate introduction. Some were selected and justified because of their reputation as pre-eminent destroyers of insect pests. The European starling achieved an expansion of its range to include North America, South Africa, Australia and New Zealand as a result of nineteenth century acclimatisation. ${ }^{12}$ It was promoted in Victoria and Western Australia (WA) for acclimatisation as a biological control agent for insect pests. It was not officially released in WA, but the continuing ambivalence over whether it was the grazier's old friend or the orchardist's 'bitter enemy' was expressed as late as $1929 .^{13}$

By the 1890s most of the Australian colonies had a dedicated department and a Government Entomologist to contribute to progressive agriculture through scientific 
practice. Expertise in addressing the problem of pest insects was fostered by the new discipline of Economic Entomology, formalised in the United States in 1889, and the entomologists' role became as much educational and political as scientific. ${ }^{14}$ The first Government Entomologists were either native-born, self-taught naturalists or Britons co-opted from colonial museums. The exception was George Compere, appointed by the Western Australian Department of Agriculture in 1901 from the Californian Board of Horticulture. ${ }^{15}$

Compere was hired amid a great popularisation of acclimatisation in Perth and belief in unlimited prospects for biological control. The decade-long defence of Compere by the agricultural bureaucracy in WA owed much to this belief, which was held strongly by the individuals who hired him. His specialist role would be to implement the 'parasite theory' and for nine years he scoured the globe searching for parasites of pest insects. Compere’s Californian connection, particularly with the famous entomologist Albert Koebele, lent authority to the program and was seen as enhancing WA's international profile and giving its scientific enterprise a modern, progressive status.

When Compere's methods drew criticism from entomologists in the eastern Australian states, particularly from Walter Froggatt in NSW, the conflict was taken up by the press and the agricultural community in WA as symbolic of a wider political divide and of their independent and outward-looking identity. Compere became a 'scientific celebrity'. His notoriety rested on several factors, not least selfpromotion. The dynamics between government, emerging professional science and agriculturalists, and their representation in the press through a narrative of conflict between experts, also enhanced his public visibility. Compere was the cat put amongst the entomological pigeons and an interstate war of words, inflamed by his 
increasingly public attacks on the methods of his 'eastern state' counterparts, contributed to a hiatus in entomological exchanges with the east. The resulting myth that only Western Australia believed in biological control persisted into the 1940s.

\section{The Western Australian Context}

In 1901 the political climate in WA was dominated by the impending referendum on Federation which was to unite the British colonies that became Australia. There was a strong push for a 'no' vote, both in the capital, Perth, and among the establishment's agriculturalists. ${ }^{16}$ This was a boom time in the west and the prospect of WA's having to share its new gold wealth, together with the loss of income from intercolonial tariffs, were seen as economic negatives to Federation. However, WA's population had tripled in the previous decade to 180,000 , with a large influx from the east to the new gold mining centres around Kalgoorlie. This, combined with the promise of a federal rail link, swayed the vote in favour of the Federation. Despite the outcome, a continuing secessionist mood prevailed, contributing to a view in some circles of the eastern states, particularly New South Wales and Victoria, as remote, condescending and controlling. ${ }^{17}$

The strength of the Acclimatisation Committee in Perth in the late 1890s, with a membership of prominent politicians and businessmen, set the mood for experimental introductions of all kinds. ${ }^{18}$ Politician and newspaper editor John W. Hackett presided over the Committee and organised the appointment of Ernest Le Souëf from Melbourne as Director of the new Perth Zoological Gardens in 1897. With the ceremonial release of two white swans from the Thames among the black swans in the ponds of East Perth Park, conducted before the Premier and local dignitaries, there was fresh interest in the acclimatisation of animals from other 
continents. This was despite the fact that acclimatisation was already out of favour in the eastern colonies, not least because some had already become serious pests. ${ }^{19}$ The acclimatisation fervour came thirty years later in WA than in other Australian colonies. However, a parallel may be drawn with post-gold rush, booming Victoria, where the Acclimatisation Society was established on the English model. As Lyndon Gillbank has argued, its official and public support came from recognition of the need to diversify Victoria's economic base from its dependence on wool. ${ }^{20}$

Like its predecessor, Melbourne Zoo, established in 1862 and directed by Le Souëf's father Alfred, Perth Zoo was one of a handful created with the dual purpose of displaying exotic animals to the public and serving as an acclimatisation and breeding centre for the introduction of potentially useful animals. ${ }^{21}$ Le Souëf favoured releasing animals such as hares, deer and starlings that were already becoming pests in Victoria. The Acclimatisation Committee challenged the Bureau of Agriculture's 1895 prohibition on the importation of the European starling because it was such a useful insectivorous bird. ${ }^{22}$ The Agriculture Department biologist, Richard Helms, pointed out the potential problems with these and numerous other suggested introductions, such as moles and ox-birds. He noted moreover that the starling had changed its habits in different climates, so it remained on the prohibited imports list. ${ }^{23}$ The corresponding public was similarly sceptical and enjoyed the disagreements between the experts. ${ }^{24}$

The introduction of parasites and predators of problem insects had already been trialled locally by Claude Fuller (1872-1928) in 1896 and the new field of biological control presented the promise of a natural, pest-free future for agriculture. ${ }^{25}$ The method focussed on alien invasive pests by introducing natural enemies from their original range. These parasites or predators were therefore 'useful' species for 
acclimatisation. James McWilliams has described the late nineteenth and early twentieth centuries as the 'heyday of biological control', when farmers, entomologists and state institutions joined in a transnational exchange of organisms, ideas and people. ${ }^{26}$ Many of the exchanges were between the 'Anglo new wests' and Australia played an early central role. ${ }^{27}$

The first big success came with the introduction in California of the vedalia beetle (Rodolia cardinalis) from Australia and New Zealand by Albert Koebele, which saved its citrus industry from the cottony cushion-scale (Icerya purchasi) in 1889. Within a decade of its detection in California's citrus orchards, the trees were covered in white egg masses of Icerya. The visibility of both pest and the predator and the dramatically rapid demise of the scale, along with grower involvement in the solution, produced a positive ideology concerning natural enemies that would last decades, despite few other clear successes. ${ }^{28}$

\section{The Appointment of a 'Travelling Entomologist'}

In 1899, after the Californian citrus industry provided funding for overseas scouting for biological control species, George Compere, the 'special agent' for the State Board of Horticulture, came to Australia looking for parasites of insects. His visit drew the attention of agricultural bureaucrats as well as entomologists and he was invited to Perth by the Director of Agriculture, Lindley Cowan, and the agriculturalist and politician Charles Harper, who, with John Hackett, was proprietor of The West Australian, Western Mail and The Daily Mail newspapers. Compere convinced them he could easily solve their insect pest problems and he was offered the position of Government Entomologist that had become available with the departures of Arthur Lea to Tasmania and Claude Fuller to Natal in South Africa. ${ }^{29}$ 
Compere also persuaded them that he would need to continue to collect parasites from those places where each pest originated.

In early 1901, Charles Harper and Adrian Despeissis (1860-1927), the Departmental Horticultural and Viticultural Expert, paved the way for employing Compere by airing his Californian credentials in the press, even suggesting that the Acclimatisation Committee should assist in rearing potential introductions to ensure a continual supply:

Such a man as Mr. Compere or Mr. Koebele is trained to the work... Any blunder or mistake made in the introduction of exotic insects, or the parasites of useful ones, might lead to such serious consequences that no one but a competent and responsible entomologist should be entrusted with the work.

(Signed) A. Despeissis.

I feel confident that it only requires a little more financial aid to fire the energies and enthusiasm of the Acclimatisation Committee, who... might work with the Department of Agriculture in a systematic endeavour ... maintaining an ever ready supply of our silent but active allies in the lower forms of life.

(Signed) Charles Harper. ${ }^{30}$

The parasite program commenced in 1902 and for the next eight years Compere travelled the world searching for parasites of pest insects, transporting them back to Perth and California, and releasing them. ${ }^{31}$ During his almost continual global travels he was in Perth just often enough to check on his latest imports, give newspaper interviews and pack for his next trip. ${ }^{32}$ Despeissis, in the supervisory role, was involved in the release of parasites around Perth and bathed in some of the media limelight during Compere’s overseas trips. ${ }^{33}$ One of Compere’s skills was the preparation of glowing reports of actual and potential successes, often touting those 
in California and Hawaii, with many details of pests defeated and costs saved. Another skill was his engaging verbal style, which matched that of an unnamed 'pressman' from the Western Mail, whose interviews with Compere read more like those in current celebrity magazines than accounts from the 1900 s. $^{34}$

\section{A FAMOUS ENTOMOLOGIST}

He was already a famous man, but his next triumph put his name in every paper. This was the discovery of the codlin moth parasite... Mr. Compere rubbed his nose, reflectively. "The American papers have been full of the codlin moth parasite find, and magazine editors have written to me from all sides asking me to write them articles. One American said that 'Compere had a nose for parasites.' But I'm too busy to worry over papers. Anyhow, this parasite business has been the best advertisement Western Australia ever had, by a long way.” 35

This was a new, strident style of science communication in Australia, as was Compere’s antagonistic disciplinary rhetoric criticising other public entomologists. While many economic entomologists had learnt to make skilful use of the media to mobilise agriculturalists and sell their message to the public, Compere appears as a master propagandist of the period. ${ }^{36}$

After several of his overseas trips there was already a polarisation of views on Compere as either a prophet or charlatan around Perth and in the orchards, but the Department remained firmly behind the promise of the 'parasite theory' he promoted. ${ }^{37}$ The 'theory' held that every insect had its own parasites in its original range, and that the balance of nature would be restored by finding and re-uniting them. Compere provided a vision of the Entomology Branch as a dispensary service of parasites by return mail for every orchard pest. ${ }^{38}$ 
Compere's enthusiasm was not shared by all entomologists, however. Even by 1902, NSW Government Entomologist Walter Froggatt (1858-1937) had written of the apparent east-west divide of opinion in the United States over the utility of parasites for agriculture. ${ }^{39}$ While the Californian school appeared to be confident that parasites would liberate farmers from pest problems, the more reticent eastern school represented by the US Department of Agriculture emphasised that only in 'exceptional and isolated' cases had parasites 'checked the ravages' of insect pests. ${ }^{40}$ A parallel east-west divide soon developed in Australian entomological opinion, as Froggatt saw a danger in the laissez-faire, 'let it slide' approach. ${ }^{41} \mathrm{He}$ believed it would compromise concerted collective actions crucial to the success of economic entomology by allowing insect pests to increase and spread.

In 1903 the WA Department failed to entice either the eastern states or New Zealand to share the funding of Compere's travels and this rejection served to heighten a sense of separation from the east and a firm link with the modern innovations of California, which from 1904 funded half the costs. ${ }^{42}$ Referring the 'bitter opposition' the offer had met, the Director of Agriculture pointed out defensively that Queensland at least 'was becoming alive to the value of this new scientific discovery of killing pests by introducing their natural enemies’ ${ }^{43}$ Aided by the press, Compere and Despeissis commenced an unprecedented denigration of the eastern states' 'kerosene entomologists' who clung to 'failed methods', alluding to pressure spraying with soap and oil emulsions. They singled out Froggatt as conservative and unwilling to admit his ignorance of the methods of introducing parasites. ${ }^{44}$

Among Compere’s claims were discoveries of parasites for two major horticultural pests: parasites of the fruit fly in India and South America, and of the codling moth in Spain. ${ }^{45}$ California and WA offered the moth parasite to the eastern Australian 
states and New Zealand for $£ 1,000$ each, but none agreed, despite the promise they could 'cry off' the bargain if it failed. ${ }^{46}$ Their attitude, as that of the South African entomologists, was to wait for any success. After all, free exchange of discoveries had characterised the biological control movement.

\section{Assistant Entomologist Frederick Lowe 'Dispensed With'}

Compere had attributed the failure of parasites to slow shipping or poor husbandry on arrival. ${ }^{47}$ An entomologist was therefore needed to receive and care for the imported parasites in the newly-built brick 'insectorium' and to deal with general enquiries during Compere’s long absences. ${ }^{48}$ While in London in January 1905, Compere visited the Natural History Museum and on the recommendation of senior entomologist George Hampson arranged for Frederick A. Lowe to be appointed as his assistant. Soon after his arrival in Perth, and in Compere’s absence, Lowe requested and obtained direct operation of Entomological Branch business from Despeissis. $^{49}$

When Compere returned from China in July, he had the previous administrative arrangement immediately reinstated. Despite having complimented Lowe on the preparations he had made for the accommodation of the insects before leaving in May, his view now changed. The trail of minutes suggests an affront at Lowe's assuming control without his instruction, but apparently there was 'a difference of opinion', and things 'rubbed along' until November when Compere was leaving for California. ${ }^{50}$ He had Lowe transferred to other duties 'on account of his lack of diligence and enterprise and also on account of Mr. Compere's distrust of Mr. Lowe', requesting that his services be 'dispensed with' ${ }^{51}$ On learning of his removal, Lowe 
sent a minute criticising Compere's methods to the new Public Service Commissioner and later complained it had been delivered via Despeissis in a 'mutilated condition'. He then 'ventilated his case' in The West Australian and included a damning list of his views on Compere's methods:

(1)The fruit fly parasite is a farce and a myth, a snare to fruit-growers, and a danger to the welfare of the fruit industry. (2) Mr. Compere has plainly served California where he came from, at the expense of Western Australia. (3) His trips are calculated to allow him to see different countries at the Government's expense. (4) The parasites he has presumed to import already exist here; moreover, they are inefficient. (5) The parasites Mr. Compere lays claim to were either introduced with their hosts or were aboriginal to this State, and have turned their attention to the imported pests. (6) The methods Mr. Compere adopts to import parasites from different places are impracticable for even short distances or times. (7) The system, as a means to combating insect pests as adopted by Mr. Compere in Western Australia, is futile and a waste of public funds. (8) Mr. Compere has again changed the hands engaged in this work, hoping thus to hide his tracks. ${ }^{52}$

The following day the Minister for Lands announced in the press that 'economy' was the sole reason for the abolition of Lowe's position, but pointedly included the Director of Agriculture's notes on the apparent discrepancy between Lowe's current criticism and the glowing comments he had made earlier in the year. ${ }^{53}$

These events precipitated an Advisory Board inquiry into the program. Lowe feverishly prepared a detailed ninety foolscap page submission to the Public Service Commissioner, Mr Jull, which dealt with numerous instances of the uncontrolled, unverified and failed releases, including the potential introduction of new pests. 
When the inquiry was held in May 1906, Lowe performed badly in his witness appearance, accusing the chairman, Mr Harper, of not being neutral because he had instigated the parasite program. Lowe refused to answer technical questions because the Board could not provide any 'technical authority'. ${ }^{54}$

The findings of the Board of Inquiry were in favour of Compere, although some questioned its impartiality:

Report of the alleged agricultural inquiry board on Compere's bugs plainly indicates bias. Believers in the parasitical theory - which is still only a theory, even in California - are styled "practical entomologists”; unbelievers are scornfully described as “professional, museum-trained entomologists.” In spite of all which cheap satire and misuse of terms the fact remains that Compere's bugs haven't done anything except die in this State. ${ }^{55}$

The submissions of numerous orchardists and Departmental officers were mediated by the Chief Inspector of Insect Pests, Mr T. Hooper, who had replaced Lowe. Even Lowe’s nominated orchardists turned against him and his formal entomological qualifications were found to compare poorly with Compere’s 'practical entomology' skills, as the newspapers reported. ${ }^{56}$

\section{WHEN EXPERTS DIFFER}

Mr Compere, whose name has been familiarised in the State by his tireless pursuit of pest parasites the world over, is undoubtedly an enthusiast with a fixed, firm, and immutable faith in his theory. He is a man of wide experience who has succeeded in convincing the Agricultural Bureau of the State of California that he is neither a crank nor a faddist and he has established himself in the good opinion of hard-headed practical men in the State of Western Australia. His theory, therefore, must be regarded with respect and cannot be permitted to be shattered by the casual assertions of Mr. Lowe, of whose qualifications not so very much appears to be generally known. ${ }^{57}$ 
Compere's confident, polished performance at the inquiry repeated the vague, local and shining overseas successes, and included an ultimatum for the Board to confirm his appointment as California wanted him to work exclusively for them. ${ }^{58}$ Lowe returned to Britain where he later reported negatively on worldwide parasite programs at the 1912 International Congress of Entomology. ${ }^{59}$ Sceptical comment about Compere's parasites continued in the local and eastern state press. WA remained up-beat, however. One headline proclaimed that WA 'beat' the 'set' that was ranged against it; the article that followed referred to their progressive projects being viewed as 'experimental, socialistic and visionary' in Melbourne, perhaps to emphasise that WA was a scientific innovator for the public good, and not in the thrall of bureaucratic self-interest or political conflict. ${ }^{60}$

\section{The Interstate 'Parasite War'}

In 1907 the Department tried once more to get the eastern states to cooperate financially in Compere's travels. But by this time, perhaps fearing they were being left behind, and criticised by their orchardists for refusing to buy the codling moth parasite, the agriculture departments of NSW, Victoria, Queensland and Tasmania had jointly decided to send Walter Froggatt on a fact-finding trip to investigate the efficacy of parasites in controlling insect pests in other countries. ${ }^{61}$ Alluding to the inflated claims made by Compere, one Sydney paper wrote that Froggatt did not go abroad 'to pluck marvels by the wayside and transmit these to the first newspaper or magazine office which he finds agape for sensational "copy", 62

The interstate 'parasite war' came to a head in 1908 when Froggatt returned to Australia from his year-long investigation. When his ship docked in Perth, Froggatt 
visited the Director, Despeissis, and the parasite facilities being maintained by the new assistant entomologist Leslie J. Newman (1878-1939). ${ }^{63}$ Newman was unable to show him any specimen collections, which existed only in Compere’s private locked cabinet, and there was little to see in the insectorium. Froggatt infuriated the Department in a press interview by stating 'I do not place the degree of importance on the parasite as the eradicator of fruit pests that Mr Compere ... does, and on this particular question I find myself at all times antagonistic to his theories' ${ }^{64}$ An interstate diplomatic incident ensued. The chief offence, however, was not about scientific practice but appeared instead to hinge on whether or not Froggatt had 'point blank refused' an offer by Despeissis to be shown the results in the gardens around Perth. ${ }^{65}$ Despeissis went on the attack, declaring Froggatt 'must have been blind during his travels in California' and he had 'merely to cross the Bight' to see what the parasites were doing. ${ }^{66}$

Compere too defended himself in the local and Sydney press, attacking Froggatt and Charles French as 'spray pot' entomologists. He claimed that Froggatt had always dismissed the parasite theory and was now unwilling to admit he was wrong. ${ }^{67}$ Compere moreover accused Froggatt of selectively visiting overseas officials 'opposed to the work from its infancy' and for good measure damned the US Department of Agriculture, claiming he would fix their gypsy moth problem if given the chance. The conflict erupted again in 1909 when Froggatt's official report was due and apparently was not supplied to WA. Every bureaucratic detail was covered by the press, which seemingly took delight in making an inflammatory defence of ‘Westralian’ rights against the eastern expert. Harper’s Daily News devoted a full page to it, including a letter from Hawaii criticising Froggatt, and one from the NSW 
Minister to his WA counterpart, concerned over the delicacy of the situation. ${ }^{68}$ There was even a call for an official apology from the NSW Government.

Although Froggatt’s communiqués from different countries had appeared in the NSW Agricultural Gazette, the agricultural journals were not seen as a forum for open critical discourse on scientific theory or practice. His final report, which contradicted Compere's descriptions of parasites being kept in check in either their native or introduced countries, was published as a separate booklet by the Department. It reviewed the state of overseas agricultural developments and attendant pest control technologies, emphasising accredited scientific and institutional arrangements. It was openly critical of adherents of the parasite theory, quoting numerous entomological authorities on failed control and elaborating on ecological reasons for fluctuating, partial effects. Froggatt saw blind faith in the parasite theory as dangerous because it compromised other sanitary practices of economic entomology. He claimed that it had delayed the passage of the NSW 'Vegetation Disease Bill' for several years because of a 'natural, if mistaken, outcry' by orchardists against spending money when the Department could just send out to other countries for parasites that would do the job. ${ }^{69}$

Things went quiet after that flurry of exchanges, chiefly because Compere ‘disappeared’ for eighteen months. When he resurfaced with a resignation letter in 1910, he was again working in California as an orchard inspector. Newman, Compere’s assistant since 1906, took over as entomologist in the Department and was described as a 'prophet', being the only one who could continue the Californian exchanges. ${ }^{70}$ Newman classed himself as an economic entomologist and worked on biological and conventional insect control until 1938. William Gurney, Froggatt’s successor in NSW, presented a paper at the 1926 Australasian Association for the 
Advancement of Science Congress in Perth, giving Newman credit for his work on biological control and lure-trapping of fruit flies. ${ }^{71}$

Figure 1. - George Compere, foreign insect collector for California and Western Australia, as he appeared in China in 1908. Image and caption from E.O. Essig, History of Entomology, New York: Hafner, 1965, p. 372, Fig. 118.

\section{The Forces of Agricultural Entomology}

Because the practice of biological control hinged on human and non-human interactions in various systems and locations, the actor-network sociological perspective and its methods might elucidate the 'heterogeneous networks' of actants in the making of George Compere. While the approach risks becoming lost in the plethora of technologies, ideas and practices that defined entomological science and drove the growth of the orchard industry, adopting Bruno Latour's terms of analysis for the WA parasite program does provide a useful descriptive framework in exploring the association of various institutional 'control groups' and other novel historical agents. ${ }^{72}$

Compere was the product of interacting forces within the WA agriculture department to secure funding and strengthen the position of a comprehensive biological control revolution. Exploiting its close links to the WA press, the agricultural hierarchy created publicity promoting the successes of the program and found that it also fitted 
well with deeper political undercurrents. The interests of the few entomological and horticultural experts, and of the agricultural bureaucrats, 'hybridised' to create a combined force of 'biocontollers' that gained the power to create 'truth' about parasites, pests and their interaction. ${ }^{73}$ The enrolment of the orchard and agricultural community was essential to the alliance. ${ }^{74}$ As in California, growers’ group conferences served to maintain a progressive consensus on the value of the parasite program. Once the biocontrollers were entrenched there was no place for dissent, as Frederick Lowe found out.

The insects themselves were central to the revolution, since success or failure depended on their interactions within the architecture of orchard plants in new environments. Both the pest host and the candidate biocontrol species needed to play their part. Without any obvious dramatic demise of common pests, what drove the program was the apparently limitless set of overseas insects amongst which to find a controlling parasite. The control of various scale pests were frequently claimed successes, but even that was contested. ${ }^{75}$ Because of their minute size the success of any parasitism was hard to measure in the contingencies of orchard life, so control over the results through the Department's Orchard Inspectors completed the power relations. The insects became visible through their 'transformation', which took place in the special building and in the office where they were displayed. Unlike in the field, they were visible here, eating or parasitising in their silk-covered glass jars, as evidence of scientific expertise. In this insectorium they were described in inflated terms to represent the controlling potential of science, although at least one journalist described a more chaotic scene. ${ }^{76}$

Part of the attraction of parasites was that they were technology- and labour-free, while sanitary methods relied on mechanical devices - the pressure spray pump and 
bait mixers, kerosene emulsions and the sure 'kill-all' of various of arsenic compounds. As the biocontrollers pointed out, these were costly, not particularly successful and had to be continually repeated. A single visible parasite success would 'displace’ all other scientific components and requirements, so entomological collections and taxonomic details were not given high priority in WA. Those in control of the program in Perth believed it would pay off, even if only 'one in fifty' were successful.

Compere was certainly a convincing entrepreneur of biocontrol, but he had a zealous personal agenda. He used Perth and the orchards of WA as his trial laboratory, bothering little over the taxonomic intricacies of his parasites and often impatiently releasing them before identification: methods viewed as unscientific by the economic entomologists. But it earned him admiration for 'action' and a practical 'instinct of observation' among the orchardists. ${ }^{77}$ It was his exaggerated claims for the 'parasite theory' and his own successes that made public conflict with his counterparts in the eastern states inevitable. They were forced to a take a stand because of the expectation and local criticism that Compere’s reports generated.

Those taking responsibility for the 'sanitation' of the orchards, the entomologists represented by Froggatt, could not join forces with the biocontrollers because the two methods were seen as incompatible. Their remedies were 'needed for today' and they designed laws to ensure the growers' compliance. ${ }^{78}$ Parasites and sprays became alternatives, although, as Froggatt reported being told in Perth ‘we can’t get the growers to clean up their orchards, so we need the parasites' ${ }^{79}$ Controversy was the result and, as a feedstock for the popular press, this became a central issue in the public sphere. The orchardists remained hopeful and their representative bodies kept faith with the biocontrollers' elegant theory and application. In 1905, the NSW 
Fruitgrowers' Union petitioned the state government to contribute to Compere’s program and in 1908 the Conference of Central Fruitgrowers in Perth still declared the parasite theory had practical value. ${ }^{80}$

The texts that form this material historic record are newspaper and agricultural journal 'mediators'. The entomologists used both to convince their constituents and the newspapers interpreted the interests of their readers. Other instruments of economic entomology, such as artists (of which NSW employed two in 1900), were not available in WA and illustrations of parasites were little used. ${ }^{81}$ Technical taxonomic descriptions in journals, such as Fuller had produced in 1897, were also absent as Compere left the identifications to the Californians.

\section{Biological Control in the two New Wests}

Western Australia's close identification with the agricultural miracle taking place in America’s golden west was not new to Australian jurisdictions. Ian Tyrrell has described the linkage between Victoria and California in sharing the vision of creating a garden landscape, based on irrigated horticulture in similar environments. He dates its commencement to the 1880s with the visits to California by the Melbourne journalists, brothers Thomas and John Dow. ${ }^{82}$ It was Victoria which first emulated the Californian citrus industry, with the establishment of the irrigation ‘colony’ at Mildura by Canadian-American entrepreneurs, brothers George and William Chaffey, in the 1890s. ${ }^{83}$

In 1901 fruit growing was no more important in WA than in NSW. It was a local industry occupying about 2,000 hectares, dispersed over numerous pockets of 
alluvial soil. But there were high hopes that refrigerated shipping and southern hemisphere seasonality would make WA fruit a major export to Britain. The total area had doubled by 1907 and, after trial shipments to Britain and Germany, commercial shipments of apples to London began in $1910 .^{84}$

Not surprisingly, the historiography of the Californian biological control movement comes largely from American environmental history and often focuses on the first 'happy accident' with the cottony cushion scale. The rivalries between the US Department of Agriculture and the Californian Board of Horticulture over credit for defeating the scale are covered in Richard Sawyer's book To Make a Spotless Orange. ${ }^{85}$ Standard texts depict Alfred Koebele as the hero explorer who 'quickly discovered' the vedalia in Australia, but a more complex story of local knowledge is revealed from its native home. ${ }^{86}$

The agricultural community in South Australia had long considered that there was a need for entomological education, having thought through the implications of the arrival of foreign insect pests in the absence of their natural enemies. ${ }^{87}$ Frazer Smith Crawford (1829-1890), an observant naturalist and horticultural advisor, whose paid job was as lithographer of town survey plans for the South Australian Lands Department, had earlier corresponded with Eleanor Ormerod in England over the source cottony cushion scale. He had suggested the introduction of a parasitic fly found in Adelaide to South African citrus orchards, where the scale had been called the 'Australian bug' since $1882 .{ }^{88}$ In Crawford's brief account, the Californian entomologist Valdemar Klee then wrote to him in 1887 requesting the parasites of $I$. purchasi for trial. He sent specimens of a fly identified as Cryptochaetum and a larger Monophlebus species to Klee and to Charles Riley’s assistant Daniel Coquillett in southern California. ${ }^{89}$ 
Koebele came to Australia in September 1888 but could find no I. purchasi around Sydney, Brisbane or Melbourne. In Adelaide however, Crawford advertised in newspapers for people to bring likely specimens to Koebele at Botanic House in Norwood and also took him to known pockets of the scale. ${ }^{90}$ Several samples of the parasitic flies were despatched to California and Koebele mentioned he had also seen Coccinelidae larvae eating Icerya. ${ }^{91}$ Koebele later reported collecting several hundred of these near Mannum on the Murray River in October, bringing them to Adelaide for shipment. Just before leaving Australia, and somewhat surprisingly, he reported finding more in the garden of the Sydney Town Hall. ${ }^{92}$ In New Zealand in early 1889, he collected thousands of $R$. cardinalis beetles on I. purchasi in orchards near Hamilton. ${ }^{93}$

Crawford's description of events suggests he was not informed of Koebele’s $R$. cardinalis collections in Australia, as in 1889 he thought the species was not known in South Australia. ${ }^{94}$ However some confusion may have arisen when another USDA entomologist, Francis M. Webster, visited in 1889 and they collected a species Webster identified as 'Coccinella concinna'. ${ }^{95}$ Crawford corrected the impression in local newspapers that he could claim having proposed the parasite introduction to Riley, but, in giving the credit for the source of the vedalia to New Zealand, he wrote of Koebele’s diversion:

... when learning from that enthusiastic and intelligent agriculturist, Mr. R. Allen Wight, of New Zealand, that the Icerya was rapidly disappearing in some parts of that colony from some unknown cause, I telegraphed to Mr. Koebele, then at Sydney, recommending him to proceed to New Zealand instead of returning to Adelaide as intended. ${ }^{96}$

Compere appears only briefly, as a later output of the hubris of the Californian biocontrollers, in most American historiography. This view of Compere in the 
USDA was expressed privately by Bureau of Entomology head L.O. Howard, who dismissed him as an uneducated and dangerous 'charlatan' likely to damage the reputation of economic entomology. ${ }^{97}$

Compere was a product of the Californian State Board of Horticulture that was still engaged in denigrating both the USDA, to claim credit for the vedalia success, and University of California academics, for continuing with fumigation research. ${ }^{98}$ During his travels for WA, he reported back to his mentors Alexander Craw, Ellwood Cooper and E. M. Erhorn in California and was immersed in the rhetoric they used against the Bureau of Entomology, borrowing their term 'kerosene entomologists' to criticise those in the eastern Australian states. An article emphasising use of both natural enemies and spraying in the Journal of Agriculture WA reflected on the wasted 'energy' of the ongoing vedalia dispute, attributing it to 'human nature' and concluded that the 'historian with judicial mind' would give equal credit to both US parties and to Crawford. ${ }^{99}$

The Californian parasite intrigues were part of the process of professionalisation of agricultural science explored by Charles Rosenberg and Paolo Palladino, when scientific authority and research moved to academically trained entomologists stationed at Agricultural Experiment Stations linked to state universities. ${ }^{100}$ Contributions of independent agriculturalists yielded to professional scientific expertise, but continued in California with political support for practical entrepreneurial figures like horticulturalist Luther Burbank. ${ }^{101}$ Entomologists in Australia were required to satisfy their agricultural, bureaucratic and scientific constituents in the manner of 'research entrepreneurs', but without the complex federal-state, academic-agricultural interplays and scale of the US professionalisation process. Government agricultural appointments were guided by 
qualification and experience, but university faculties of agriculture were only established in $1911 .^{102}$

Direct funding from the citrus industry and the State insulated the Californian Horticulture Board from research-enterpreneurial pressures during 1900-1910. The inspection and enforcement powers of the Boards (whose entomological staff were agricultural businessmen or former inspectors), and their political connections, enabled the 'parasite' program to continue independently. The momentum was maintained by positive feedbacks of knowledge from the Board and funding from the economically and politically powerful citrus industry representatives. ${ }^{103}$ University field experiment stations had been established in the 1880s, but biological control only became part of the Berkeley agriculture program in the $1920{ }^{104}$

In WA it was the Agriculture Department that provided the funding and controlled the knowledge through its agricultural journal. It also managed quarantine and orchard inspections as well as several Experimental Farms. The Californian antipathy toward federal control of entomological authority was transposed to other state government entomologists in Australia and was expressed in the same terms, driven by a perception of the national government seated in, and representing, the ‘eastern states’.

\section{Politics and Celebrity Science}

Western Australia might have thought that interstate financial cooperation in the parasite program would be a logical outcome of Federation. The rejections became a point of political contention and perceived insult at multiple levels. The eastern state 
agriculture ministers' decisions were based on the advice of their entomologists, in whose expertise they expressed faith. But Compere had become a celebrity and his frequent, convincing presence in the newspapers spread his claims far and wide. In NSW it became a political issue from 1902 and the agricultural public were watching. The State Member for the horticultural district around Sydney, Frank Farnell, questioned the Agriculture Minister in Parliament about 'bringing nature' to the aid of pest control as was evident in California and WA. ${ }^{105}$ A local candidate even took the 'parasite theory' to the 1907 election platform, declaring there was 'something in it' that should be investigated. ${ }^{106}$

During the 1900s, the heyday of the Australian local newspaper, the metropolitan and regional press transmitted knowledge by reprinting one another's articles. ${ }^{107}$ For practical scientific knowledge they also lifted from agricultural journals. Scientific good news and controversy travelled relatively quickly via the telegraphic network. Through his reports, Compere controlled knowledge of insects from the overseas locations he visited and the positive view of parasitic control in WA was bolstered by the coverage the parasite program received in the Californian press and horticulture journals. The eastern states' decision to send Froggatt overseas reflected their difficulty in reconciling both the sensational and indifferent reports, and goes some way to explaining the detailed counter examples in his official report.

Compere and Froggatt were portrayed in the press not only as having polar approaches to insect pest control, but as scientific opposites. Compere’s public appeal came, in a manner similar to Luther Burbank’s, from his image as a self-made practical man challenging scientific convention. ${ }^{108}$ Froggatt was represented in WA as the interference by 'stiff-necked' eastern experts and an encroachment of rigid scientific authority into agricultural practice. ${ }^{109} \mathrm{He}$, too, held no academic credentials 
but had adapted to the norms of the scientific community. He had paraphrased L.O. Howard in 1898 to the effect that suspicion of and resistance to entomologists by farmers was a major challenge to his discipline. In reality their expertise was respected by most Australian agriculturalists, who had few traditions to defend. ${ }^{110}$ Froggatt was singled out for attack because he was Compere's most public critic and was perceived to have approached the issue with preconceived bias.

Despite Compere’s claims of eastern states’ denial of parasites, biological control had been scientifically investigated by the economic entomologists both before and during his Australian tenure. Their exchanges were through more official channels and they were careful to stress that successes would be rare. ${ }^{111}$ Henry Tryon in Queensland had discussed parasites of insects as early as 1896 and was a member the Prickly Pear Control committees in $1912 .{ }^{112}$ Froggatt investigated parasites of caterpillars, blowflies and orchard pests. They all fostered the education of agriculturalists in identifying beneficial insects, searched for locust parasites, and trialled Charles French’s entomophyte 'Cape fungus'. ${ }^{113}$

Figure 2. - 'Government Entomologist, Mr Walter Froggatt, conducting locust exterminating experiments at Goodwill, Condobolin, NSW' (The Australasian, 17 November 1902, p. 33). The trials were part of a biological control program using the imported ‘Cape fungus’ to kill locusts.

The idea that the eastern states’ entomologists not only knew nothing of biological control but purposely denigrated the concept was a myth that grew along with that of 
Compere. And myth is hard to shake once entrenched, particularly when state pride is involved. Reviewing the contributions of 'Science in Agriculture' in 1933, the year there was a majority vote in favour of separation from the Federation in a WA referendum, the Minister for Agriculture, G.L. Sutton, called Newman 'Compere’s apprentice’ and recalled:

... on my arrival in this State some 20 years ago, the present Government Entomologist (Mr. L. J. Newman) was practically the only entomologist resident in Australia who believed and advocated biological control methods; other entomologists preferred to rely upon the spray pump, and other artificial means of control. It is to Mr. Newman's credit that, despite opposition and some-times ridicule, he had consistently advocated biological control throughout this period. The principle is now generally accepted throughout Australia and in other parts of the world. ${ }^{114}$

That view was not just political rhetoric but persisted also in the scientific sphere. In the Presidential Address to the Royal Society of WA in 1946, Newman's successor Clee F. Jenkins, summarising the status of biological control in WA, said that the early critics were ill-informed and that Froggatt had 'rather bitterly attacked' Compere’s work. But Compere’s provocations had been in the press rather than official documents, and so were lost to Jenkins’ domain of historical enquiry. ${ }^{115}$

\section{Popular Public Science}

Economic Entomology was public science in the historical sense of governmentfunded 'applied' science, linked to government policies and under the imperative to demonstrate its worth to agriculturalists. It was part of the grand project of building 
Australian identity through agricultural development. ${ }^{116}$ It communicated through agricultural journals, lectures and demonstrations, but the 'parasite theory' was also 'public science' because of its popularisation in the press.

In light of James Secord's reminder that 'popular science' is an inadequate descriptor for the complexities of public engagement in scientific histories, there was more to the exposure that 'parasites' received in the press than simple scientific exposition to have ideas accepted. ${ }^{117}$ The conflict between experts made it all the more popular. As Michel Biesunski identified in the early reception of relativity theory in France, 'people were excited by the fact agreement had not been reached', opening a simple schema of popularisation as transmission of knowledge to instances of 'scientific controversy’. ${ }^{118}$

Biological control was also popular science because any observant person could contribute to its discovery and application. The government entomologists' and plant pathologists' rooms in the eastern states were at times crowded with a backlog of candidate organisms sent in by the public for evaluation. ${ }^{119}$ The principles and proof of 'parasites' were not esoteric or removed from everyday experience. ${ }^{120}$ Rather they were understandable in terms of the familiar concept of the 'balance of nature' and the arcane issues of Latinate taxonomies confounded even the experts.

When correspondents from the east and the west contributed poems about the flaws they saw in this public science, the science had clearly entered what Katherine Pandora has identified as ‘vernacular culture’, producing diverse, unauthorised scientific discourses. ${ }^{121}$ The satire was directed mainly at government, questioning its role and ability to direct agricultural development in its 'alliance' with science, but the 'disagreements between experts' also appealed to people who were reluctant 
to yield their own natural-historical experience to experts seen as their scientific equals. ${ }^{122}$ The early professionalization of agricultural science may have drawn out lingering tensions over the nineteenth century establishment of scientific authority by professional accreditation and expertise. ${ }^{123}$

\section{Conclusion}

In Australia, biological control was initially an extension of acclimatisation, because the establishment of imported controlling organisms in the new environment was a necessary precondition to any success, and the justification for introducing numerous animals was as insect pest controllers. This connection was specified during the late, brief blooming of acclimatisation in WA.

While the historiography of acclimatisation societies in the second half of the nineteenth century often focuses on the 'ecological imperialist', sentimental, or otherwise odd motivations of some of its practitioners, it was justified at the time in Australia by its agricultural economic merits. ${ }^{124}$ Thus the Queensland and South Australian Societies, when petitioning government for grants in the 1860s, used the argument that existing agricultural industries were based on introduced species and gave long lists of potential organisms, particularly plants, to be acclimatised. ${ }^{125}$ The movement played a significant role in early agricultural development in Australia, as its societies were a conduit for the free exchange of information, cultivars and seeds of potential crops, and trees and forage grasses. ${ }^{126}$ By 1905, when the Queensland society disbanded, it had distributed more than 500 accessions of tropical grasses and legumes. ${ }^{127}$ But the practice of acclimatisation continued during the twentieth century. Pastoralists in northern Australia continued the deliberate introduction and 
dissemination of many tropical grasses and legumes to boost cattle production, and were assisted in the selection of species by scientists during the 1970 s and 1980 s. ${ }^{128}$

Although the negative consequences of some acclimatisations were already clear in 1901, the prior risks for parasitic insects were hard to foresee and in WA were deferred to Compere's expertise. Froggatt's concerns perhaps arose from naturalist interests and instincts that were broader than entomology. He had been against the active 1890s acclimatisations of starlings in the east and was a prescient lone voice in the wilderness against the release of the cane toad for biological control of cane grubs in the 1930 s. $^{129}$

Political, institutional and individual motivations all influenced the early growth and practices of biological control in Australia, reflecting the social and local emplacement of science. Knowledge was largely produced by overseas experience and was differently transmitted, filtered and interpreted in local contexts in west and east Australia. The Western Australians were reassured by news of great successes and the scale of infrastructure being committed to biological control in California and Hawaii, while in the east the science of economic entomology stood firm with established practices and a more cautious view of parasites’ potential.

The sense of separateness in the west was reinforced by claiming a scientific ‘disciplinary space’ around the attractive logic of parasites as 'nature’s own remedy' for pests. ${ }^{130}$ With Compere as its famous 'younger school’ emblem, WA agricultural bureaucrats established scientific authority over methods of biological control, defending and defining them by opposition to 'old-fashioned' eastern entomological ideas and practice. ${ }^{131}$ Their ideological commitment to the program was used as a scientific symbol of state identity, comparing it to revolutions in medical science 
decried by entomologists in the east still 'clinging as tenaciously to their sprayingpumps as did the medico of old to his leeches'. ${ }^{132}$

The principle of the 'parasite theory' was based on ecological ideas of natural population regulation and remains a fundamental methodology of classical biological control. Compere argued, perhaps following ideas of William Fiske about ‘superparasitism' that, while a single parasite would never completely eliminate an introduced pest, the combined action of several would free producers from the cycle of spraying. ${ }^{133}$ He managed to 'find' parasites for those pests he was told were most needed and had rightly warned of potential hyperparasites in one of his shipments to California. ${ }^{134}$ But he was also well aware of the potential economic gain a major success might bring. ${ }^{135}$

Although at the colourful end of the spectrum, Compere was part of a much wider phenomenon. Other entomologists, such as Claude Fuller and Charles P. Lounsbury working in South Africa were also travelling overseas to find parasites, including to South America to find Compere's 'fruit fly Staphylinid'. ${ }^{136}$ The USDA sent Charles Marlatt to China to find scale parasites and, in 1905, L. O. Howard commenced a major federal-state project for a biological solution to destruction of forests by the gypsy moth. ${ }^{137}$ But Compere and the Californians were outsiders in established entomological circles and were dismissed as methodological renegades, making them passionate advocates of the 'theory'.

The biological control ‘heyday’ continued for several decades and in 1927 Britain embraced the concept as part of a post-war 'defensive imperialism'. ${ }^{138}$ The Empire Marketing Board (EMB) funded the conversion of a country house in Buckinghamshire into a 'Parasite Zoo' for the evaluation, breeding and dispensing of 
insects for biological control throughout the British Dominions. Scientists from the Imperial Bureau of Entomology reportedly equipped Farnham Royal 'to provide the sinews of a war to the death on insects that are the deadly enemies of farmers and fruitgrowers in every country under the sun' ${ }^{139}$

In Australia, the first Chief of the new Council for Scientific and Industrial Research (CSIR) Division of Economic Entomology, Robin Tillyard, outlined a program to attack the major insect and weed pests of agriculture by biological control in 1928. The very real prospect for biological control of prickly pears at that time lent CSIR head David Rivett's support for his approach. ${ }^{140}$ While on a visit to Perth, Tillyard was reminded of and acknowledged WA's foresight in the new science. ${ }^{141}$ Australia fared better financially than other dominions during this period of 'science for empire' in consequence of the shared enthusiasm for biological control. Tillyard's hopeful linkage with Farnham Royal resulted in his failed release of a French blowfly parasite, but the significant outcome was the EMB effectively funding half the Divisional budget during its first five years, which allowed the completion of the CSIR laboratories in Canberra and the continued operation of its entomology programs during very uncertain times. ${ }^{142}$

By way of a postscript to Compere’s contribution to classical biological control, there were many insect introductions in Western Australia during 1901-1910; in fact more than in any other decade of the twentieth century throughout Australia. ${ }^{143}$ Clee Jenkins' meticulous 1946 reconstruction of releases shows, however, that most of the few successes were arranged through official channels, either from the eastern states or South Africa. This was one place Compere did not visit and apparently he rarely contacted officials in other more exotic places. His connection with the Californian Board of Horticulture did allow several parasites that had already proven viable in 
orchards there to be sent to WA, but it remains unclear if any of the more than 100 largely unknown species released from his world travels were successful. ${ }^{144}$

* Fenner School of Environment and Society, College of Medicine, Biology and Environment, Australian National University, Canberra, Australia, 0200.

Email: edward.deveson@anu.edu.au

\section{Acknowledgements}

The foresight of the National Library of Australia and the various State Libraries in the digitisation of Australian newspapers (the 'Trove' project) enabled many of the hidden details to this chapter of scientific history to be recovered. My employer, the Australian Plague Locust Commission has supported my research on aspects of the history of Australian entomological science, which are part of $\mathrm{PhD}$ studies in environmental history at the ANU. Marc Poole of the WA Department of Agriculture and Food provided early references by Claude Fuller. I thank Charlotte Sleigh, Pip Deveson, Libby Robin and two anonymous referees for their valuable comments.

\footnotetext{
${ }^{1}$ Cumberland Argus and Fruitgrowers' Advocate (Sydney), 1 Aug. 1903, p. 8.
} 
${ }^{2}$ Sunday Times (Perth), 10 Dec. 1905, p. 1.

${ }^{3}$ G.V. Maynard, J.G. Hamilton and J.F. Grimshaw, 'Quarantine - Phytosanitary, sanitary and incursion management: an Australian entomological perspective’, Australian Journal of Entomology, (2004) 43, pp. 318-328.; p. 320. They refer to Aconophora compressa, a tree hopper species released in 1995 to control lantana, was found damaging native trees in 2003; The Victorian, Ballarat, NSW and Qld Acclimatisation Societies introduced Ligurian honeybees in the 1860s, when 'British' bees were already naturalised.

${ }^{4}$ Raymond Wright, “Dispensed With” A.R. Wallis, first Secretary for Agriculture in Victoria 18721882. Department of Agriculture of Victoria, Research Project Series No 150, December 1982. Melbourne. pp. 24-25. The first colonial biosecurity legislation was introduced in 1880 after Phylloxera appeared in Victorian vineyards. Alexander Wallis' sacking hinged on political claims of misconduct during the Phylloxera eradication campaign; Adelaide Observer, 1 Apr. 1882, p. 11; 18 Aug. 1888, p. 9.Concern in the 1880s centred around the consequences of the introduction of the hessian fly, most likely through straw packing in imported products. As a pest of wheat and other grains it would be a potentially serious pest and the fact that it would have no natural enemies was discussed by the South Australian Agriculture Bureau. As an example of the biosecurity risks posed by plant imports during the period, in 1897 WA recorded import of 55,000 cases of fruit, 20,000 vines and 20,000 pot plants. Producers' Gazette and Settlers Record Western Australia (1898) 5 (1), p. 70.

${ }^{5}$ Sheila Wille, 'The ichneumon fly and the equilibration of British natural economies in the eighteenth century’, British Journal for the History of Science (2015) 48 pp. 939-660. Wille explores the heyday of interest in the parasitic Hymenoptera 'ichneumon fly', from 1770 to 1860 . Wille proposes an alternative view of evil actions of eating caterpillar hosts 'from the inside out' for the fascination, identifying it instead as a metaphor for a combination of agricultural production, population and social control issues; J.H. Perkins and R. Garcia, 'Social and economic factors affecting research and implementation of biological control' In T.S. Bellows and T.W. Fisher (eds) Handbook of Biological Control, San Diego: Academic Press, 1999, pp. 993-1009. Like numerous scientific references on the discipline, they authors mentions Linnaeus, Kirby and Spence and Darwin, as presaging the potential of insect biological control.

${ }^{6}$ Richard C. Sawyer. To Make Spotless Orange. Biological Control in California, Iowa University Press: Ames, Iowa, 1996, p. 19. A large contingent of Iowa townsfolk came to Riverside in the 1870s.

${ }^{7}$ The Daily News, 26 May 1909, p. 9.

${ }^{8}$ G.M. Gurr, N.D. Barlow, J. Memmott, S.D. Wratten and D.J. Greathead, ‘A History of Methodological, Theoretical and Empirical Approaches to Biological Control' in S. D. Gurr, G. M. and Wratten, S. D. (eds.) Biological Control: Measures of Success, Dordecht: Kleuwer, 2000, pp. 337, table p. 7.

${ }^{9}$ Peter Coates, American Perceptions of Immigrant and Invasive Species: Strangers on the Land, Berkeley: University of California Press, 2006, p. 8. Coates identifies the notion of 'mobile nature' as useful for the uncontrollable spread of invasive species in the USA. Chapter 3 deals with racial connotations of parallels with human and animal immigrations.

${ }^{10}$ C. R. Warren, 'Perspectives on the 'alien' versus 'native' species debate: a critique of concepts, language and practice’, Progress in Human Geography (2007) 31, pp. 427-436. Pest species were seen as negative on equivalent agricultural grounds to Charles Warren's proposed 'damage criterion' for biological conservation priorities.

${ }^{11}$ D. M. Richardson, P. Pysek, D. Simberloff, M. Rejmanek and A. D. Mader, 'Biological invasion as - the widening debate: a response to Charles Warren’, Progress in Human Geography (2008) 32, 295 298. Gives a critique of Warren in the conservation context, which is applicable to agriculture; FAO report of $28^{\text {th }}$ Conference. ' $G$ ' International Standards for Phytosanitary Measures, http://www.fao.org/docrep/x5585e/x5585e0i.htm; R. U. Ehlers (ed) Regulation of Biological Control 
Agents, Dordecht, Springer, 2011. More stringent tests of possible negative consequences for nontarget organisms were introduced from the 1920s.

12 John L. Long, Introduced Birds of the World: the worldwide history, distribution and influence of birds introduced to new environments, Terrey Hills NSW, Reed, 1981, pp. 359-362.

${ }^{13}$ C. F. H. Jenkins. 'The Starling’, Emu (1929) 29, pp. 49-50; Andrew P. Woolnough, M.C., Massam, R.L Payne and G.S. Pickles. 2005. 'Out on the Border: Keeping Starlings out of Western Australia', Proceedings of the 13th Australasian Vertebrate Pest Conference, Te Papa Wellington, New Zealand, 2-6 May 2005, pp. 183-189. In the 1970s the Agriculture Protection Board and the Department began a long-term program to eradicate incursions from the east across the Nullarbor Plain and shooters still manned the border with South Australia into this century.

${ }^{14}$ W.W. Froggatt, 'Economic Entomology in Australia’ Agric. Gaz. NSW. (1898) 9, pp. 131-138. Froggatt detailed the progress of the new discipline. The first annual meeting of the Association of Economic Entomologists took place in Washington on 12 November 1889; Adelaide Observer, 1 Apr. 1882, p. 11; South Australian Register, 4 September 1882, p. 6. The term 'economic entomology' had been in general use in Britain for more than a decade after publication of the book of the same name by Andrew Murray in 1877. In Adelaide, Frazer Crawford had recommended the creation of a Museum of Economic Entomology in 1881, and referred to students of 'economic entomology' in an address the Royal Agricultural and Horticultural Society of South Australia.

${ }^{15}$ Daily News, 23 Nov. 1905, p. 5; George Compere was born in Davenport, Iowa. He moved to California and at age 20 and was in charge of a large orchard in Los Angeles in the 1890s. (http://earlyaviators.com/ecompere.htm - cited 15 April 2013). He became an Inspector for the County Board of Horticulture, then the California Board, and took a position in Hawaii in 1898. His son Harold Compere (1896-1978) was an early aviator and followed George in the trade of biological control in 1919, gaining credit for the collection of a parasite of the mealybug in Australia in 1927.; The West Australian, 17 Jun. 1933, p. 6. Compere was said to have been a French Canadian by his former assistant, L.J. Newman in a lecture given at the Royal Society of Western Australia on 'Scientific Conflict with Insects'.

16 Thomas Musgrave. 'Western Australia’s Secessionist Movement', Macquarie Law Journal (2003) 3, pp. 95-129.

${ }^{17}$ The Sunday Times, whose proprietor James MacCallum Smith favoured secession, began publishing openly secessionist articles in 1907, which continued to the 1930s. The movement culminated in a referendum on secession in 1933 in which a majority of electorates and voters opted for withdrawal from the Commonwealth of Australia.

${ }^{18}$ The West Australian, 15 Jun. 1897, p. 4. Committee members also included, George Throssell, Justice E.A. Stone, Charles Lee Steere and W. Paterson.

${ }^{19}$ Peter Minard, 'Assembling Acclimatisation: Frederick McCoy, European Ideas, Australian Circumstances', Historical Records of Australian Science (2013) 24, pp. 1-14. The Acclimatisation Society of Victoria active introductions were in decline by the 1870s. It was renamed the Zoological and Acclimatisation Society, which reflected its new preoccupation with the display of exotic animals.

${ }^{20}$ Linden Gillbank, 'The Origins of the Acclimatisation Society of Victoria: Practical Science in the Wake of the Gold Rush’, Historical Records of Australian Science (1986) 6, pp.359-374.

${ }^{21}$ One other notable acclimatisation zoo established around that time was Barcelona Zoo in 1892 under the directorship of Francesc Darder. Darder's vision of acclimatisation for ecological socialism was presented by Oliver Hochadel at the 2014 BSHS conference.

22 'Destructive Birds', Producers Gazette and Settlers Record Western Australia (1898) 5 (1), pp. 2829; The West Australian, 24 Jan. 1898, p. 3; Western Mail, 28 January 1898, p. 15; Le Souef was a 
strong advocate of starlings to solve all kinds of insect problems. Despeissis suggested the introduction of numerous other birds such as woodpeckers and nightingales.

${ }^{23}$ The Inquirer and Commercial News, 28 Jan. 1898, p. 4. Helms was quoted as being 'tooth and nail' against the introduction of starlings.

${ }^{24}$ West Australian Sunday Times, 12 Jun. 1898, p. 7. 'Expert Experts ... I have often wondered why it is that our imported, highly-educated, experienced, well-paid experts often disagree.... we lose confidence in experts generally when one of them makes a statement-as a fact- and he is directly contradicted by another Government expert or by scientists who are recognised as authorities on a subject.'

${ }^{25}$ Clee F.H. Jenkins. 'Biological Control in Western Australia', Presidential Address, 1946. J. Royal Soc. W.A. (1947) 32, pp. 1-17; p. 2. Claude Fuller was born and educated in Sydney, and worked as an entomologist in Africa from 1899. His final, fatal appointment was as Chief Entomologist in Mozambique in 1928.

${ }^{26}$ James E. McWilliams. 'Biological control, Transnational exchange and the construction of environmental thought in the United States, 1840-1920', in E.M. Bsumek, A. Kinkela and M.A. Lawrence (eds.), Nation-states and the Global Environment: New Approaches to International Environmental History, Oxford: Oxford University Press, 2013, pp. 163-180.

27 The terms 'newlands' and 'new wests' are used by James Belich to characterise settlement booms in the inland of both colonial and ex-colonial countries. See: James Belich, Replenishing the Earth. The Settler Revolution and the Rise of the Anglo World, 1783-1939, Oxford: Oxford University Press, 2009, p. 85.

${ }^{28}$ Richard C. Sawyer. To Make Spotless Orange. Biological Control in California, Iowa University Press: Ames, Iowa, 1996. p. 15.

${ }^{29}$ Lea and Fuller, and the biologist Richard Helms, all moved to WA from positions in the NSW Department of Agriculture; The Daily News, 26 May 1909, p. 9. Harper (MLC) was joint proprietor with J.W. Hackett (MLC), who was also the editor.

30 The Inquirer \& Commercial News, 1 Feb. 1901, p. 11. Harper inserted a letter describing Compere's work. Despeissis in the same issue replied, saying that such a man as Compere, a 'specialist' and 'competent entomologist' was trained for this painstaking work.

${ }^{31}$ Among the places Compere visited on parasite business were Spain, Italy, France, Asia Minor, Palestine, India, Ceylon, the USA, Brazil, Timor, Japan, China, Hong Kong, Philippines and England.

32 Western Mail, 18 Jul. 1903, p. 5; Daily News, 7 Nov. 1905, p. 12. Compere was in Perth for just 10 days.

${ }^{33}$ Western Mail, 6 Jun. 1903, p. 5. Mauritian born Despeissis was a graduate of Britain’s Cirencester Agricultural College. He was also an early advocate of acclimatisation and suggested a long list of birds in 1898.

${ }^{34}$ Examples of the style of the particular 'pressman' include; Western Mail, 3 Jun. 1905, p. 70.

'Bronzed and travel-weary with the dust of three continents and the spray of as many seas comparatively fresh upon him ... Compere, grand chief insect hunter, returned...; The Daily News, 14 Jul. 1903, p. 1.; The Daily News, 26 May 1909, p. 9. 'Mr Compere’s face was a story without words'.

35 The Daily News, 26 May 1905, p. 10. ‘codlin moth’ was a common usage for the insect now known as the codling moth.

${ }^{36}$ Compere came from California at a time when Randolph Hearst's newspapers were transforming US the media from partisan political to sensational 'yellow' journalism. See: William J. Bernstein, 
Masters of the Word: How Media Shaped History, New York: Grove/Atlantic Press, 2013, pp. 20811 .

${ }^{37}$ Compere attributed the parasite theory to Alexander Craw of the Horticulture Board in the 1880s.

${ }^{38}$ The Daily News, 14 Jul. 1904, p. 1.

${ }^{39}$ The Australasian, 22 Nov. 1902, p.15. Froggatt differentiated the 'eastern’ and Californian 'schools'.

${ }^{40}$ W.W. Froggatt, 'The limitations of parasites in the destruction of scale insects', Agricultural Gazette of NSW. (1902) 13 (11), pp. 1087-1093, p. 1092

${ }^{41}$ Froggatt, op. cit. (40), p. 1092.

42 Western Mail, 15 Aug. 1903, p. 10. The West Australian, 10 Aug. 1904, p. 7; Cooper also made the offer to New Zealand, Journal of Agriculture W.A. (1906) 13, pp. 457-458.

${ }^{43}$ Western Mail, 28 Jan. 1905, p. 10. The Department received a letter from the Qld Dept., expressing an interest in the findings of parasite introductions; The Daily News, 2 Feb.1905, p. 1. reference to interest by Claude Fuller, then Natal Entomologist; The Daily News, 30 Nov. 1905, (Second Edn.), p. 5. The cost of Compere's travels and program were questioned in the WA Parliament.

${ }^{44}$ Western Mail, 15 Aug. 1903, p. 9; Western Mail, 3 Jun. 1905, p. 7. Compere calls Froggatt and others 'kerosene entomologists'.

45 The Daily News, 28 Nov. 1904, p. 10; The Daily News, 28 May 1904, p. 9.

46 The Daily News, 26 May 1905, p. 10; 16 Jun. 1906, p. 4.; Australian Town and Country Journal, 31 May 1905, p. 11.; Western Mail, 15 August 1903, p. 10.

${ }^{47}$ Western Mail, 21 Feb. 1903, p. 10.

48 The West Australian, 16 Jun. 1905, p. 3. The windowless insectorium was built on the Public Park side of the Agriculture Department building in St Georges Terrace.

${ }^{49}$ The West Australian, 20 Dec. 1905, p. 8.

${ }^{50}$ Western Mail, 23 Dec. 1905, p. 9.

${ }^{51}$ The Daily News, 26 May 1905, p. 10.

${ }^{52}$ The West Australian, 19 Dec. 1905, p. 7.

53 The West Australian, 20 Dec. 1905, p. 8; Western Mail, 23 Dec. 1905, p. 9. Lowe claimed that the two assistants who were to replace him were each paid more than he was.

${ }^{54}$ Western Mail, 19 May 1906, p. 6. One of Compere’s methods was to import whole trees infested with both unidentified pests and parasites but this, along with refrigeration, had been standard practice since Koebele’s 1889 shipments.

55 Sunday Times, 16 Sep. 1906, p. 4. An earlier example from The West Australian, 23 Feb. 1906, p. 6. 'When the Director of Agriculture institutes the inquiry he has promised into the vexed question of parasite v. sprays. etc.. who will constitute the tribunal now that he has publicly expressed his views in favour of parasites and allowed the chief inspector to do likewise? It seems to me in withholding the contrary views, we are not getting both sides of the question, such as a jury requires. Expressing a verdict before the case is heard in open court is to say the least, indiscreetly unfair. Yours. etc., T. HEWETT-HOEY. Perth, February 17.' 
${ }^{56}$ The Daily News, 25 May 1906, p. 4. ; 26 May 1906, p. 8; Western Mail, 24 Feb. 1906, p, 8. Hooper was then in charge of the local part of parasite program, having swapped offices with Lowe in September 1905.

${ }^{57}$ Bunbury Herald, 30 May 1906, p. 2

${ }^{58}$ Western Mail, 26 May 1906, p. 6.

${ }^{59} \mathrm{~K}$. Jordan and H. Eltringham, Proceedings of the Second International Conference on Entomology. Oxford, August 1912, London, 1914, p. 43.

${ }^{60}$ The Daily News, 16 Jul. 1906, p. 4. The editorial article was repeated again on p. 8. The article was about the eastern states' blind refusal to buy the codlin moth parasite. Referring to the Melbourne press, 'they would have it that WA is a mining camp, with a convict settlement in the background, and a few poppet heads in the foreground'. The term 'socialistic visionary' was common in the newspapers at the time to describe the conflicts in federal politics between Deakin's Protectionist government and the 'socialist' Labor opposition and fears of the nationalisation of some agricultural industries. I have not found any article in the Melbourne press critical of Compere's methods find no Belich, op. cit. (27), p.359, describes government overfunding of railways during booster development in Canada and Victoria as an example of bureaucratic 'public choice' theory.

${ }^{61}$ Walter Froggatt, Report on Parasitic and Injurious Insects: 1907-08, Sydney: NSW Department of Agriculture, 1909, 78 pp, p. 1.

The West Australian, 13 Mar. 1907, p. 9. WA requests eastern states’ financial contribution.

${ }^{62}$ The Sydney Morning Herald, 24 Jun. 1907, p. 7. 'Mr Froggatt has kept a level head all though the time during which the discoveries of the fruit fly, codlin moth and other parasites have been blared out in American and other publications.'

${ }^{63}$ Queensland had insisted that Froggatt investigate the program in WA at the end of his trip.

${ }^{64}$ The West Australian, 18 Jul. 1908, p. 6; The West Australian, 27 Jul. 1908, p. 4. On a stopover in Adelaide he was quoted as saying to the state minister 'I have no more faith in the value of parasites as an absolute solution of the orchard pest problems than before I undertook the trip.

${ }^{65}$ Froggatt, op. cit. (61), pp. 56-57. Froggatt was adamant there had been no such offer, writing that he had offered to stay a further week if there might be anything to see and Despeissis had 'distinctly answered that there was nothing more to show me, either in the office or the orchard', and that Despeissis had said there would be nothing to see in winter.

${ }^{66}$ The Daily News, 11 Jul. 1908, p. 2.

${ }^{67}$ The West Australian, 14 Apr. 1895, p. 3.

${ }^{68}$ The Daily News, 15 Sep. 1908, p. 8. Contained a full page of detailed columns on the Froggatt snub to WA. Much seemed to hinge on detailed recounts of conversations between Newman, Despeisses and Froggatt, over who had 'point blank' refused whom; Sunday Times, 16 Apr. 1905, p. 4; Sunday Times, 19 Nov. 1905, p. 7. When the WA Department had tried to get the eastern states to contribute to the 'Westralian' parasite program, there were several supportive letters to the papers.

${ }^{69}$ Froggatt, op. cit. (61), p. 69.

${ }^{70}$ Sunday Times, 22 May 1910, p. 8.

${ }^{71}$ The West Australian, 28 Aug. 1926, p. 12.

${ }^{72}$ Bruno Latour, The Pasteurisation of France, (trans. A. Sheridan and J. Law). Cambridge, Mass: Harvard University Press, 1988, p. 12. Bruno Latour's analysis of the way that different 'control 
groups' were unified through 'networks of association' around the central scientific figure of Louis Pasteur during the French microbiological 'revolution' set the example for agnostic, ethnographic reading of a documentary historiography from scientific journals.; See also: Richie Nimmo, 'Actornetwork theory and methodology: social research in more-than-human world', Methodological Innovations Online (2011) 6 (3), pp. 108-119. Nimmo has shown how the methods could be applied to an agricultural setting in examining the commodification of milk in Britain.

${ }^{73}$ Latour, op. cit. (72), p. 56. 'hybridisation of the Pasteurians and the hygienists multiplied the power of both'.

${ }^{74}$ Michel Callon, 'Some elements of a sociology of translation: domestication of the scallops and the fishermen of St Brieuc Bay’, in J. Law (ed) Power, Action and Belief: A New Sociology of

Knowledge? London: Routledge, 1986. pp. 196-223, p. 206. Enrolment is defined as the successful result of 'enterresement' in building alliances.

${ }^{75}$ Compere and Despeissis often cited the defeat of scale insects, in particular black scale, which they said had previously covered trees in Perth. But even this claim was contested by a correspondent 'Evergreen' in the West Australian, 22 Apr. 1909, p. 6, who directed Compere to various trees close to where the parasites were housed to find black scale.

${ }^{76}$ Examples are given here of reference to scientific control of a potential pest, of the anthropomorphised descriptions of the insects' activities, and of the actual situation in the insectorium: The West Australian, 26 May 1905, p. 7, 'at present some 10,000 odd flies [imported fruit flies] are thriving under State management and control'; The Daily News, 14 Jul. 1904, p. 1. 'on all sides were mysterious jars teeming with insects of every type ... the fruit fly parasite, captured and brought home safely.; The West Australian, 16 Jun. 1905, p.3. Mr. Compere carefully lifts a rotten orange and discloses an ugly black centipede-beetle thing with a shiny back. "There's a beauty enthuses the learned breeder; "Isn't he doing well? See the grubs he's been at! What is he? Why, he's Staphylinidae--predaceous beetle on the fruit fly. There are thousands of him already-you'll find him in nearly every piece of fruit. Ah! that chap you're looking at now is the fruit fly proper. Have a look at him through this glass...; The Daily News, 26 May 1905, p. 10. 'On the floor, on the tables, on the shelves - on everything that could hold it, was piled decomposing fruit. The air was heavy with the stench of the fruit, and with insects. To breathe through the mouth was to inspire countless flies. And the heat was insufferable. 'See that one! He's got a maggot. Here, come and have a look at him.' The representative of 'The Daily News' climbed over a case of aged fruit, and peered underneath a shelf into a conglomeration of insects, maggots, dirt, and fruit.'

77 The West Australian, 22 Jul. 1908, p. 3.

${ }^{78}$ Windsor and Richmond Gazette, 16 Feb. 1907, p. 7.

${ }^{79}$ Froggatt, op. cit. (61), p. 68.

${ }^{80}$ Cumberland Argus and Fruitgrowers' Advocate, 9 Sep. 1905, p. 7; The Daily News, 27 Aug. 1908, p. 10; West Australian, 27 Jan. 1908.

${ }^{81}$ One of the few illustrations used in WA journals was a rough sketch of a chalcid fly parasite of fruit fly from India by E.H. Bailey.in: L. J. Newman, 'The Fruit Fly Parasite', Journal of Agriculture W.A. 17 (July 1908), pp. 561-563.

${ }^{82}$ Ian R. Tyrrell, True Gardens of the Gods: California-Australia Environmental Reform 1860-1930. Berkeley: University of California Press, 1999. They were despatched by different newspapers.

83 J.M. Powell, 'Enterprise and Dependency: Water Management in Australia', in T. Griffiths and L. Robin (eds), Ecology and Empire: Environmental History of Settler Societies, Carlton South, Victoria: Melbourne University Press, 1997, pp. 102-121, p. 112. 
${ }^{84}$ Western Perspectives on a Nation, Library Information Service of Western Australia. The Land, http://slwa.wa.gov.au/wepon/land/html/orchards.html, cited 24 July 2015; Trial shipments of apples were made to London and Bremen in 1906, Journal of Agriculture W.A. (1906) 13, p. 3.

${ }^{85}$ Sawyer, op. cit. (27), p. 16.

${ }^{86}$ A. L. Olmstead and P. W. Rhode, Creating Abundance: Biological Innovation and American Agricultural Development, New York, Cambridge University Press, 2008. pp. 246-248;

Sawyer, op. cit. (28), p. 14; McWilliams, op. cit. (26), p. 175; J. E. McWilliams, American Pests:

The Losing War on Insects from Colonial Times to DDT, New York, Columbia University Press, 2008, p. 90.

${ }^{87}$ At meetings of the Horticultural and Agricultural Society, the Gardener's Society established in the 1850s, and the Agricultural Bureau in the 1860s, there were discussions and publication of information on injurious insects and of invasive threats posed by such insects as the hessian fly from Europe. Adelaide Observer. 18 Aug. 1888, p. 9; For discussion of the learned societies established in early the utopian settlement of the South Australian colony see: E.D. Deveson, 'The Adelaide Philosophical Society and the early accommodation of the Darwin-Wallace theory of Natural Selection', Trans. R. Soc. S.A. (2013) 137, pp. 151-167.

${ }^{88}$ South Australian Register, 4 Sep. 1882, p. 7. At a Gardener’s Society meeting Crawford mentioned it had been introduced from NSW.

${ }^{89}$ South Australian Register, 5 Oct.1889, p. 7. Crawford was born in Scotland and spent time in Sydney and Melbourne before moving to Adelaide in 1861. Crawford was a member of the South Australian Bureau of Agriculture, the Royal Agricultural and Horticultural Society of South Australia and the Farmer's Club. He was also a professional photographer and wrote several booklets on fungoid and insects pests of orchards in the early 1880s, which included the first use of photographs of plant diseases.

${ }^{90}$ Adelaide Observer, 6 Oct. 1888, p. 12.

${ }^{91}$ Australian Town \& Country Journal, 17 Nov. 1888, p. 21.

92 University of California, Riverside. 'Biological Control of Arthropods, Weeds and Molluscs' http://www.faculty.ucr.edu/ legneref/biotact/ch-35.htm - cited 24 July 2015; Sydney Town Hall itself was unlikely to have been be a site for either Icerya or Rodolia in 1890, as the building did not have a garden. However, acacias were also a host of Icerya, so the adjacent cathedral garden could have harboured them. See:

http://www.powerhousemuseum.com/collection/database/?irn=32139\&utm_source=api\&utm_mediu

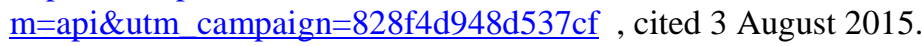

${ }^{93}$ Edward O. Essig, History of Entomology, New York: Hafner, 1965 (facsimile of 1931 edn.), p. 373. Compere's acceptance of the WA position may have been influenced by his recall to Sacramento in 1900 because of budget constraints on the Bureau's 'explorations'.

94 South Australian Register, 5 Oct. 1889, p. 7.

${ }^{95}$ Although from the same Family, that species, the seven spotted ladybird, appears distinct from Rodolia, other Coccinella spp., such as $C$. tranversalis, might be mistaken for $R$. cardinalis.

${ }^{96}$ South Australian Register, 5 Oct. 1889, p. 7.

${ }^{97}$ Sawyer, op. cit. (28), p. 45.

${ }^{98}$ Sawyer, op. cit. (28), p. 27.

99 ‘Saving California’s Fruit Crops’, Journal of Agriculture W. A. (1906) 13, pp. 333-338, p. 338. 
${ }^{100}$ Charles Rosenberg, 'Science, Technology and Economic Growth: The Case of the Agricultural Experiment Station Scientist, 1875-1914’, Agricultural History (1971) 45 (1), pp. 1-20. Rosenberg discusses how the politics of dealing with multiple constituent interests required directors to become 'research entrepreneurs';

Paolo Palladino, 'Wizards and Devotees: on the Mendelian Theory of Inheritance and the Professionalisation of Agricultural Science in Great Britain and the United States, 1880-1930', History of Science (1994) 32 (3), pp. 409-444.

${ }^{101}$ Palladino, op. cit. (100), pp. 416-417.

102 WA appointments Fuller, graduated from Melbourne University, Despeissis from Britain's Cirencester Agricultural College, and Newman from Burnleigh Horticultural College in Victoria. Victoria established agricultural colleges in the 1890s and had numerous graduates by 1901.

${ }^{103}$ Sawyer, op. cit. (28), pp. 29-31.

${ }^{104}$ Sawyer, op.cit. (28), p. 50; Rosenberg, op. cit. (100), p. 12. Eugene Hilgard at the University of California established an experiment station in the 1880s; C. P. Clausen, 'Biological Control of Citrus Insects' in W. Reuther, E. C. Calavan \& G. E. Carman (eds), The Citrus Industry Vol 4. Berkeley: UCANR, 1967 (Revised 1978), pp. 276-317; p. 278.

${ }^{105}$ Cumberland Argus and Fruitgrowers’' Advocate, 1 Aug. 1903, p. 8.

${ }^{106}$ Cumberland Argus and Fruitgrowers’ Advocate, 25 May 1907, p. 11. Liberal candidate H.E. Pratten said 'there is something in the 'parasite theory' and should be followed up.

${ }^{107}$ In the period 1900-1910 there were over 160 newspaper titles in NSW and 25 in WA; one for every 10,000 and 8,000 persons respectively (Trove, http://trove.nla.gov.au/newspaper/search?adv=y ) accessed 10 Feb, 2015. This does not include some short-lived titles that have not survived for digitisation.

${ }^{108}$ Katherine Pandora, ‘Knowledge held in common’, ISIS (2001) 92, pp. 484-516.

${ }^{109}$ Western Mail, 18 Jul. 1903, p. 5.

${ }^{110}$ Walter Froggatt, op. cit. (14).

111 The West Australian, 28 Dec. 1907, p. 9. French commented that the eradication of fruit fly by parasites was unlikely and that in only a few instances had parasites been successful.

${ }^{112}$ Henry Tryon, 'Insect Friends and Foes’, Queensland Agricultural Journal (1897) 1, pp. 465-472; p. 471.

${ }^{113}$ The Australasian, 30 Sep. 1899, p. 9. Froggatt and French investigated native fungoid disease of the caterpillar pest; The Brisbane Courier, 20 Apr. 1898, p. 5. Tryon investigates a brachonid wasp parasite of the Qld fruit fly.

${ }^{114}$ Western Mail, 5 Jan. 1933, p. 33.

115 Clee F.H. Jenkins 'Biological Control in Western Australia', Presidential Address, 1946. Journal of the Royal Society W.A. (1947) 32, pp. 1-17; p. 2.

${ }^{116}$ Libby Robin, How a Continent Created a Nation, Sydney: UNSW Press, 2007. Robin traces the history of agricultural and environmental sciences, including the wool industry which was seen as a patriotic project of economic nation building, and multiple attempts at the agricultural development of northern Australia.

117 James A. Secord, ‘Knowledge in Transit', ISIS (2004) 94 (4), pp. 654-972, pp. 670-71. 
${ }^{118}$ Michel Biesunski, 'Popularisation and scientific controversy: the case of the theory of relativity in France. in: T. Shin and R. P. Whitley (eds) Expository science: forms and functions of popularisation. Sociology of the sciences No. 9. Yearbook 1985, Dordecht : D. Reidel Publishing, 1985. pp. 183-194; p. 185.

${ }^{119}$ D. Mc Alpine, Agricultural Journal of Victoria, (1904) 3, p. 469.

${ }^{120}$ Ludwig Fleck, Genesis and Development of a Scientific Fact, (eds) T. J. Tren and R. K. Merton. Chicago: University of Chicago Press, 1979 (original 1935 in German). p. 82. Scientific ideas and evidence that is removed from everyday experience is one characteristic of Fleck's specialised esoteric scientific knowledge.

121 Katherine Pandora, op. cit. (108), p. 492.

122 W.W. Froggatt, Presidential Address 1912, Proceedings of the Linnaean Society of NSW. (1913) 37, pp. 1-43; p. 10. Froggatt described 'the alliance of Government with science' in relation to development of the Northern Territory.

${ }^{123}$ Richard Yeo's exemplified these tensions in his analysis of the popularity, anonymity and criticism of Robert Chambers' Vestiges. See: Richard Yeo, 'Science and intellectual authority in midnineteenth century Britain: Robert Chambers and "Vestiges of the Natural History of Creation"', Victorian Studies (1984) 28 (1), pp. 5-31; The early practitioners of progressive agriculture also filled their journals with articles on the necessity of cultivating a 'scientific culture'. eg. J.M. Fowler, 'Scientific Culture', Producers Gazette and Settlers Record Western Australia (1898) 5 (1), pp. 272275.

124 Thomas Dunlap, 'Remaking the Land: The Acclimatisation movement and Anglo ideas of Nature', Journal of World History (1997), 8, pp. 307-319. Dunlap focuses on the nostalgic attempts to recreate and repopulate European nature; Harriet Ritvo 'Migration, assimilation and invasion in the nineteenth century’, in J. Frawley and I. McCalman (eds) Rethinking Invasion Ecologies from the Environmental Humanities, Oxon: Routledge, 2014. pp. 17-30. Ritvo focuses on the odd motivations behind the acclimatisation of several animals.

${ }^{125}$ Chris Tiffen, 'Five Emus to the King of Siam: Acclimatisation and Colonialism', in Helen Tiffen (ed), Five Emus and the King of Siam: Environment and Empire, Cross/Cultures 92.

Amsterdam: Rodopi B.V., 2007, pp. 165-176; p.166. Tiffen gives the example of the Qld Society; Adelaide Observer, 13 Feb. 1864, p. 2. Mr. Lindsay argues in the House of Assembly for funding the South Australian Acclimatisation Society on the grounds of developing agricultural produce to supplement wheat, particularly in bad seasons, to stock the country with 'productions which would, in the economical point of view, promote its material interest'.

126 The Sydney Morning Herald, 27 Jun. 1865, p. 5; The Queenslander, 3 Oct. 1874, p. 5.

${ }^{127}$ R. J. Clements and E. F. Henzell, 'Pasture research and development in northern Australia: an ongoing scientific adventure’, Tropical Grasslands (2010) 44, pp. 221-230, p. 223.

${ }^{128}$ During the 1950s-1980s they were assisted by scientists in the selection and improvement of species through the Tropical Pastures Society, in what could be construed as another late flowering of the movement: see Clements and Henzell, op. cit. (127), p. 225; During the 1970s and 1980s , a number of cultivars were bred by CSIRO scientists, see R. J. Williams and R. J. Clements, 'The future of role of plant introduction in the development of tropical pastures in Australia', Proc. $3^{\text {rd }}$ Australian Conference of Tropical Pastures 8-12 July 1985, pp. 20-28, p. 26.

\footnotetext{
${ }^{129}$ Nigel Turvey, Cane Toads: A Tale of Sugar, Politics and Flawed Science. Sydney: Sydney University Press, 2013. pp. 144-147.
}

${ }^{130}$ Western Mail, 6 Jun. 1903, p. 5; For the application of the spatial and knowledge domains of disciplinary space in the context of ecological science, see: Steven Bocking, 'Science and Spaces in the Northern Environment', Environmental History (2007) 12, pp. 867-894. 
${ }^{131}$ Western Mail, 6 Jun. 1903, p. 5.

132 Western Mail, 3 Jun. 1905, p. 7.

${ }^{133}$ Western Mail, 4 Jan. 1908, p. 6; Sawyer, op. cit. (28), p. 51.

134 Sawyer, op. cit. (28), p. 48.

135 The Daily News, 23 Jul. 1904, p. 1. In an interview Compere commented about one insect that 'if a few years ago he had had that branch of parasites, he could have got half-a-million dollars for it'; Western Mail, 12 May 1906, p. 4.

${ }^{136}$ Froggatt, op. cit. (61), pp. 66-67.

137 Olmstead and Rhodes, op. cit. (86), p. 249, table pp. 254-256.

${ }^{138}$ Libby Robin, 'Ecology: a science of empire?’, in Griffiths, T. and Robin, L. (eds) Ecology and Empire. Environmental History of Settler Societies, Carlton, Victoria: Melbourne University Press, 1997, pp. 63-75; p. 67. Robin cites Michael Worboys in characterising British foreign policy in the interwar period as 'defensive imperialism', but motivations may have been as much inclusive and economic as an attempt to secure the colonies through development.

${ }^{139}$ Brisbane Courier, 10 Sep. 1927, p. 26.

${ }^{140}$ C.B. Schedvin, Shaping Science and Industry: a History of Australia's Council for Scientific and Industrial Research, 1926-49, Sydney: Allen and Unwin in Association with CSIRO, 1987, p. 87.

${ }^{141}$ Mirror (Perth), 21 Sep. 1928, p. 14. Tillyard spoke at a Roy. Soc. Meeting and was reminded by Charles Catton Grasby.

${ }^{142}$ Western Mail, 3 Jan. 1929, p. 43. The EMB offered to provide the Division $£ 25,000$ for capital expenditure and $£ 37,000$ over five years for maintenance, subject to the Commonwealth making similar contributions; Robin, op. cit. (138), p. 67.

${ }^{143}$ D.F. Waterhouse and D.P.A. Sands, Classical Biological Control of Arthropods in Australia, Canberra: CSIRO \& Australian Centre for International Agricultural Research, 2001; M. P. Zalucki, 'From natural history to continental scale perspectives: an overview of contributions by Australian entomologists to applied ecology - a play in three acts', Austral Entomology (2015) 54, pp. 231-245, Figure 4, p. 235.

144 Jenkins, op. cit. (115), total numbers were calculated from references and tables given. 